\title{
Rural Household's Risk Attitude and Credit Rationing: The Case of Chongqing in China
}

\author{
Xinjun Pang1, Yunwu Kuang1, Xiaohong Gong2 \\ ${ }^{1}$ Department of Business and Trade, Southwest University, Chongqing, China \\ ${ }^{2}$ The Bureau of Land Resources and Housing Management, Chongqing, China \\ Email: 479650640@qq.com, pangxinjun1981@163.com
}

Received 18 October 2014; revised 22 November 2014; accepted 4 December 2014

Copyright (C) 2014 by authors and Scientific Research Publishing Inc.

This work is licensed under the Creative Commons Attribution International License (CC BY). http://creativecommons.org/licenses/by/4.0/

CC) (i) Open Access

\section{Abstract}

This paper identifies farmers' risk attitude through ELCE method and problem design that conducts a survey of 237 rural households in Chongqing Municipality, and empirically studies the relationship between risk attitudes and credit rationing by utilizing Probit and Logit model. The results show that farmers' risk attitude and credit rationing are a significant positive correlation. The stronger farmers' risk aversion is, the more serious the demanded credit rationing becomes. Risk attitude which is determined the risk cost and risk premium, thus affects the credit behavior and credit rationing degree. In addition, distance of peasant's residence away from the city and their land amount have a positive significant influence on credit rationing, while the factors, such as farmers' education level, income, family labor force, have a negative significant effect on credit rationing. Based on these findings, the paper further analyzes the relationship between farmers' credit using and credit rationing to farmers with different risk attitudes. Measures to relieve the farmer's credit rationing must be taken from government, financial institutions and farmers respectively.

\section{Keywords}

Risk Attitude, Credit Rationing, Risk Cost, Chongqing

\section{Introduction}

Credit plays an essential role in the "issues of agriculture, farmers and rural areas" in China. Through formal and informal financial channels, credit functions is allocating resources, promoting production and transaction, diversifying risk, and thus it promotes rural development in general; through proving circulating capital and investment loan to rural enterprises and rural households, credit makes rural enterprises grasp investment opportu- 
nities timely and farmers apply modern agricultural technology and mode of production, and consequently credit speeds up the transference of rural labor force to the secondary and tertiary industries (Zhang Longyao and Jiang Chun, 2011 [1]). Zhu Xi and Li Zinai (2007) [2] point that rural household credit increases farmers’ income as a whole.

Li Rui and Zhu Xi (2007) [3] show if credit rationing exists in rural areas, especially among rural households, farmers will have trouble getting necessary capital, which will have a negative effect on the increase of their welfare and farmers' average net income will drop 9.55\%. But an important question arises: Does such credit rationing exist? If the answer is yes, then what are the reasons? Zhang Jie (2005) [4] regards it is an unsolved mystery. Scholars home and abroad draw different conclusions after their respective research. Cheng Yu and Luo Dan (2010) [5], for example, believe that although "industry re-feeding agriculture and city supporting countryside" policy and the advancement of urban-rural integration relieve the rural credit rationing, it is still not uncommon. It is estimated that China's rural households with credit demand reach over 70\%, the average credit gap is 4420 yuan (RMB) and their demanded credit gap accounts for 56.7\% of the total. Yang Jun (2010) [6] think most of the farmers who have obtained the credit are facing serious "service rationing" and "quantity rationing”. Inness Love and Susana M. Sancbez (2009) [7], after a research of credit and investment of individual entrepreneurs, agriculture and non-agricultural enterprises in Mexico, point out that credit rationing is common especially for individual entrepreneurs. However, Zhu Xi, Shi Qinghua and Li Rui (2010) [8], after the survey of 10,357 rural households in the Yangtze River Delta, conclude that credit rationing is closely related to credit using: if the credit is used in agriculture itself, there is no credit rationing; otherwise credit rationing arises. Zhong Chunping (2010) [9] also holds that there is no obvious credit rationing and demanded credit of the majority can be satisfied based on the research conducted in Anhui Province in China. Subhash and Kochar (1995) [10], on the basis of a research in developed countries, believe that credit supply for rural households is sufficient and the reason why farmers get less credit is due to inadequate demand. In addition, scholars pay more attention to rural households' credit in less-developed areas (Huo Xuexi et al., 2010 [11]; Kong Rong et al., 2009 [12]; He Mingsheng, 2008 [13]), but less attention to that in the developed areas. The reason why the above scholars get various conclusions is mainly because they haven't taken the farmers' individuality into account. Many scholars believe that credit rationing chiefly occur in less developed areas, but farmers' risk attitudes and farmers' credit rationing in developed areas, is the one of the most important factor in studying farmers' credit issue in China. Farmers' credit issue in developed areas differs from that in under-developed areas, and farmers' risk attitudes have a different effect on credit rationing and credit using, consequently influence farmers' credit behaviors. Ma Xiaoyong and Bai Yongxiu (2011) [14], for instance, contend that farmers' risk aversion has less effect on formal credit balance but negative effect on informal credit constraint, while Chen Yu and Luo Dan (2009) [15] hold that farmers' risk aversion enhance their awareness of credit cost, which decreases credit grant expectations and causes demanded credit constraint.

According to Von Neumann-Morgenstern (M-N) model, as to the risk attitudes, farmers can be divided into risk lovers, risk averts and risk neutrals. Farmers are traditionally labeled as risk averts and risk neutrals, but Kim Tae-Hun (2011) [16] finds that farmers' attitudes changes with the passage of time. Schultz in his book Reconstructing Traditional Agriculture points out that farmers, like enterprises, are pursuing maximum profit and they will get profits through financing as long as there is investment opportunity. Farmers with different risk attitudes have different credit needs, which causes demanded credit rationing; as to the investment chances, farmers' risk attitudes will change too, so as the process of credit rationing (Millard F. Long, 1968 [17]). The past researchers either take it for granted that credit rationing exists in farmers or deny such credit rationing blindly and there lacks consideration of farmers' individuality, especially research of the relationship between farmers' risk attitudes and farmers' credit constraint in developed areas. The paper points out whether there is credit rationing or not, it is mainly because farmers' risk attitudes are determined by risk cost and risk compensation and thus influencing farmers' credit behavior and credit consequences (including credit rationing).

With the development of the secondary and tertiary industry, farmers' non-agricultural income is increasing rapidly as results of industrialization of the developed areas and urbanization process. Farmers' risk attitudes (or risk pattern) have changed obviously, and their credit behaviors have taken on such new features as the increase of life-improving credit demand and financial asset allocation demand (Luo Junqin, 2010 [18]). In the transitional period of China, there lacks economic literature about farmers' credit conditions in light of their different risk attitudes in developed areas, and this paper just fills such a gap. It is very significant for the financial development of China's middle-income rural areas to study farmers’ credit features on the basis of farmers' risk 
aversion theory. This paper conducts a survey of 237 rural households in Chongqing Municipality in China, puts such variables as risk attitudes, credit constraint, farmers' features and geographical factors into the same model and analyzes farmers' credit behaviors with regard to their various risk attitudes.

The structure of the paper is as follows: the second part is about the theoretic hypotheses of risk attitudes, farmers' credit and credit rationing, the third part is to analyze the risk attitudes of 237 farmers and their specific features, the fourth part is to establish and verify the measure model of farmers' risk attitudes and credit constraint, and the fifth part is the conclusion and proposed policies.

\section{Theoretic Hypotheses of Risk Attitudes and Credit Rationing}

\subsection{Hypothesis I: The Stronger the Farmers' Risk Aversion Is, the Higher Their Compensation Demand of Risk Cost, and the More Easily They Are Influenced by Credit Constraint. As to Risk Lovers, the Less Likely They Are Affected by Demanded Credit Constraints}

When studying farmers' credit behaviors under certain and uncertain condition. In a given productive chance, farmers' credit behavior is closely related to their own risk attitudes and project yield rate. With the increase of farmers' income, farmers prefer to undertake more risks, which makes absolute risk aversion drop. Furthermore, the features of farmers' risk aversion determines their preference to maintain certain income, but avoid risk cost brought by credit, and then credit constraints are manifested as demanded risky credit constraint. The combination of systematic credit constraint and farmers' risk preference forms the convergence of demanded credit mechanism and reinforces farmers' suppressed preference in credit demand.

\subsection{Hypothesis II: Farmers' Credit Using Affects Their Credit Rationing in Light of Their Different Risk Attitudes. When Farmers Are Risk Averts, Their Basic Living Credit Rationing Is More; When They Are Risk Lovers, Their Credit Rationing Is Mainly about Life Improvement and Investment}

If farmers are risk averts, and various transaction cost from credit and risk cost are relatively big, farmers either prefer contracts with certain profits or voluntarily withdraw from the credit, which makes farmers' credit demand lower than expected. Therefore, demanded credit constraint arises, which has a negative impact on farmers' welfare to some degree.

As shown in Figure 1, $\bar{y}$ stands for farmers average income, $\delta$ is the arbitrary positive deviations from the average income. Farmers' random income can be shown by one half of the two income $(\bar{y}+\delta, \bar{y}-\delta)$. The expected utility of farmers' random income can be shown as the half of the two income utility level:

$$
E(u)=1 / 2 u(\bar{y}+\delta)+1 / 2 u(\bar{y}-\delta)
$$

The utility function is a concave function (can also be a convex function or straight), therefore:

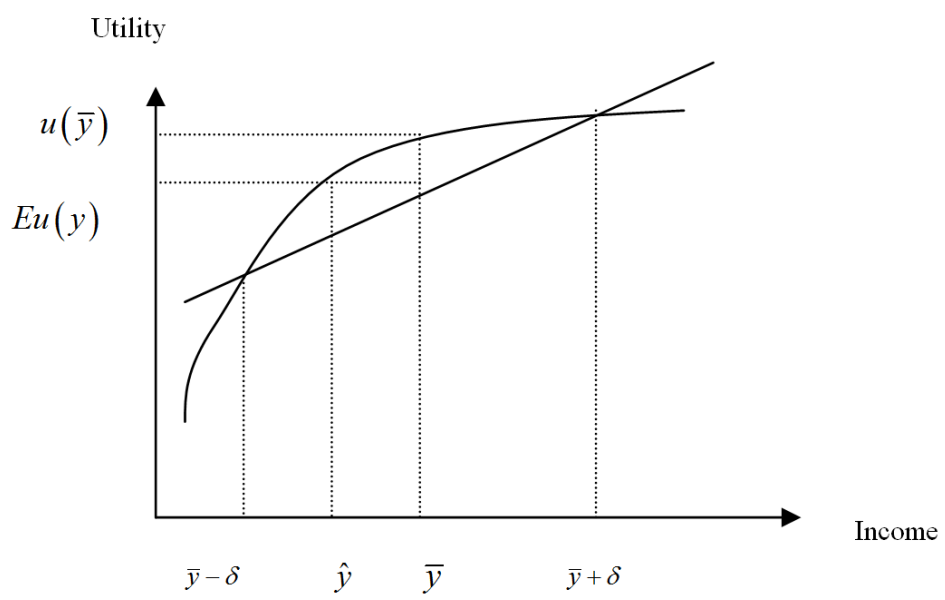

Figure 1. Farmers' risk aversion, income and utility. 


$$
E(u)<E(\bar{y})
$$

Suppose, $r c=E(\bar{y})-E(y)$ then $r c$ is the measurement of risk cost of expected utility. In terms of money, producers are asked how much certain income they would like to give up in order to get the same utility of risk cost. Suppose utility level of income $\hat{y}$ is the same as $y$, that is $u(\bar{y})=E u(y)$, then $\Delta y=\bar{y}-\hat{y}$ means risk premium.

Risk premium $\Delta y$ depends on both the utility function (whether it is concave, convex or straight) and incomes distribute probability. Curvature stands for the level of risk aversion. If $E u(y)>u(y)$, farmers are risk lovers; if $E u(y)=u(y)$, farmers are risk neutrals; If $E u(y)<u(y)$, they are risk averts.

Suppose farmers' total wealth is $W$, the part used in production is $k$; the labor input is $L$, and production technology remain unchanged. Without credit behaviors, the yield of the farmer is $Q^{n b}$, and $Q^{n b}=f(k W, L, X)$, in which $X$ is the vector of farmers' feature that affects the production. In order to enlarge production the amount of credit farmers get is $B$ with the interest $r$ because of credit from financial institutions, and $B=f(W)$; the yield of this time is $Q^{b}$, and $Q^{b}=f\left(k W+B, L^{b} ; X\right) . L^{b}$ is the labor input after credit behavior. The probability of success in their project is $\theta$; The probability of failure in their project is $1-\theta$, therefore $Q^{f b}$ appears and $Q^{f b}<Q^{n b}<Q^{b}$. In order to get credit, farmers need to pay interest $r B$, transaction cost $F$ as well as risk cost due to uncertain income of farmers with different attitudes $r c$.

The condition under which farmers choose credit is as follows:

$$
E(y)=\theta Q^{b}+(1-\theta) Q^{f b}>Q^{n b}+r B+r c
$$

$E(y)$ stands for farmers expected income with the credit.

According to formula (3), the greater transaction cost, the more likely the farmers have to give up credit because of the high cost, and thus the demanded credit rationing arises. Farmers with different risk preferences also tend to abandon credit application for the demanded risk cost cannot be compensated; hence the demanded risky credit constraint appears.

As shown in Figure 2, horizontal axis displays farmers' needed funds, vertical axis stands for various costs because of credit. If when farmers expected income is $E(y)$, there is no transaction cost and risk cost. When there is transaction cost $F$ and risk cost $r c$, and the funds that farmers need are $N_{1}$ and $N_{2}$ respectively. Therefore, the constraint amount of risk cost is $N_{c d}=N_{0}-N_{2}$. If farmers' risk aversion is much stronger, the curve moves upward to the left, and bigger $N_{c d}$ is.

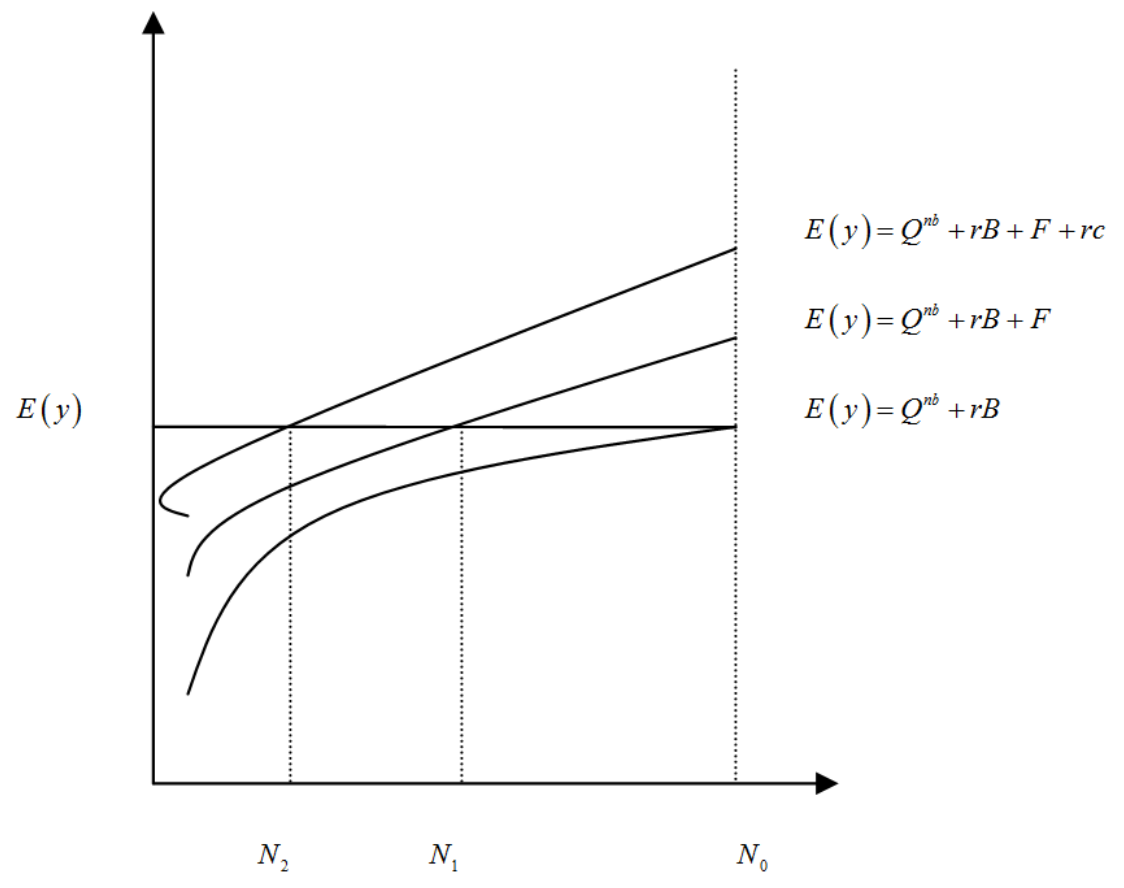

Figure 2. Farmer’s demanded risk credit constraint. 
When farmers are risk averts, they would try to minimize the risk. And if they have the need for credit and its purpose is for basic living expenses and thus life maintenance credit appears due to the lack of mortgage. With the increase of their income, farmers' attitudes would gradually change to risk-taking. On the one hand, the increase of their income means more opportunities to investment, and their investment benefit will rise too. On the other hand, the increase of their income means farmers will be more optimistic about future expected income, and their credit demand to better their life will increase. However, credit constraint appears because of investment risk, worries about macroeconomic environment and restrict of financial institutions.

\section{Descriptive Analysis of Farmers' Risk Attitudes, Socioeconomic Conditions and Credit Characteristics}

Farmers' risk attitudes determine farmers' credit behaviors and the consequences. As to the measurement of the risk attitudes, direct method of N-M model and its indirect method (equivalent method) are applied. In practice, based on ELCE and ELRO, interview and experimenting are uses to find out respondents' risk attitudes. Given farmers' ability to answer questionnaire, distribution of risk attitudes and common methods used home and abroad, the paper mainly applies ELCE to find out farmers' risk attitudes.

In ELCE method, the equivalent is obtained from risk produce and utility value matching method. Suppose utility value of the best risk produce is 1 , utility value of the worst is 0 , and probability of the both is 0.5 . Risk prospects of discrete pay are shown as $\left(x_{1}, x_{2}, \cdots, x_{n} ; p_{1}, p_{2}, \cdots, p_{n}\right)$, in which $x_{i}$ is the pay of $i, p_{i}$ is the probability of the pay of $i$, and $\sum p_{i}=1$. First, farmers are asked to identify between the best and the worst risk produce a non-risk produce (certain equivalent), which equals the combined utility value of the two risks produces. Then farmers are inquired again to identify between the last non-risk produce and the worst risk produce (or the best risk produce) another non-risk produce, whose utility value equals the combined utility value between the former non-risk produce and the worst risk produce (or the best risk produce). The above process will be carried out continuously until farmers' risk attitudes are completely elicited.

As to measure risk constraint, the questions in the paper are designed as follows: Do you need credit? If yes, do you obtain the total amount you have asked for? Do you apply for credit voluntarily or do you give it up right after the application or is your application rejected? If farmers don't need credit or they have obtained the full amount of their credit, they are not restricted by credit constraint. If farmers who need credit don't apply voluntarily or give it up automatically after the application, such cases are defined as demanded credit constraint.

The survey of this paper is conducted in Chongqing, a relatively developed city with 38 counties. Scale economy and individual household economy coexist there, and there are strong motivations for financing demand. First, the total sample sum is determined, and then the household number of each county (including the agricultural demonstration park) is fixed according to its respective population and the two-stage sampling method is used here. In the first stage, villages are randomly selected from each town. In the second stage, farmer households are randomly selected from the villages chosen from the first stage. The survey was conducted by students from Southwest University in July and August of 2013 with the help of urban-rural integration office of Chongqing. The survey chiefly covers the households' features, risks they have, agricultural characteristics, geographic factors and rural financing market. 244 households have been investigated while 237 valid questionnaires have been collected.

\subsection{Sample Farmers' Risk Attitudes}

Among 237 sample farmers, risk averts are 76, accounting for 32.06\%, while risk neutrals and risk lovers amount to $35.44 \%$ and $32.50 \%$ respectively. It is interesting that the percentages of all the three risk types are very close, whereas the past researches show that most farmers are risk averts. The reason may be that sample farmers are in developed areas and economic situations there in general are quite good, whereas farmers' risk attitudes are closely related to wealth.

\subsection{Sample Farmers' Features and Social Economy}

- Among the 237 households, the distances between their home and the city vary: some live in the city, the farthest distance is 50 kilometers while most live about 20 kilometers away from the city. As to the number of the family, the minimum is 1 person and the maximum is 8 persons in total and the average is about 4 
persons. The labor force of the family reflects its ability to create wealth, and the average labor force is 2 , which shows that micro-unit of rural economy is rather small in general. The various distances cause the asymmetry of credit information, which may lead to credit constraint. Without mechanized farming, fewer labor forces may cause less family income, which may result in family fund gap.

- The average age of householders is 41.46, and the percentage of householders aged from 30 to 50 reaches $82.70 \%$. The reason why there are fewer younger householders is that many youths go out to work due to rural labor surplus. The general education level is high, the average level is high school and the percentage of those with above high school diploma accounts for $81.01 \%$. The total family operating income below 10,000 yuan amounts to $2.53 \%$, the average family operating income is 70,230 yuan, and the total family income above 100,000 reaches $23.63 \%$. The above data show that the farmers in Chongqing have comparatively higher education level and much wealthier, which is tied up with its developed economy and favorable geographic location and market influence.

- When answering the question "What is the main source of your income?" 145 farmers choose industry, accounting for $61.18 \%$; those who choose plantation is $38.82 \%$; and only 28 people choose agricultural product processing. Family operating income and salary form work in the city are the main sources of family total income because developed industry of Chongqing provides farmers with many job opportunities.

\subsection{Analysis of Farmers' Credit Behaviors}

When answering the question: "what is the major channel for you to get credit?" $30.26 \%$ householders have chosen private capital, especially their relatives and friends as shown. 59.63\% farmers have chosen financial institutions (including Rural Credit Cooperatives, Agriculture Bank of China and other commercial banks), 5.81\% have chosen usury and other channels accounts for $4.28 \%$. The above statistics proves that farmers still rely on loan from relatives and friends, which is contrary to the theory that in the developed areas formal financial institutions shall be the major channel. This mainly results from the high transaction cost, complicated credit procedures and high credit risk with loan from formal financial institutions.

Farmers mainly have chosen 6 - 12 months and 1 - 3 years credit terms, and that is to say, the medium term loan reaches $51.79 \%$. The credit period within three months amounts to $7.18 \%$, while that over 5 years is $7.18 \%$. In short, rural credit in Chongqing is chiefly medium term, whereas the short term and long term are less. The amount of financing reflects how much fund farmers need. 61.42\% farmers have the credit limit of above 30,000 yuan, which shows that the credit amount is relatively high in Chongqing. $18.78 \%$ farmers have the credit limit of over 100,000 yuan, while only $17.26 \%$ farmers have the credit limit of below 5000 yuan.

\subsection{Analysis of Sample Farmers' Credit Rationing}

According to the six types of demanded credit rationing put forward by Zhao Binqi (2010) [19], dates show the distribution of the various types. The credit rationing percent of sample farmers reaches 55.70\%, among which $50.75 \%$ credit rationing appears because farmers are afraid of the loss of mortgages or they are pessimistic about investment prospects. $44.69 \%$ farmers choose not to get credit due to the high credit rate, $29.55 \%$ farmers withdraw from credit because of complicated credit procedures, 29.54\% farmers don't apply for credit just because of their poor social relations, $15.91 \%$ farmers abandon credit because of the worry of losing face, while $6.82 \%$ farmers are afraid of the harsh punishment as a result of breach of contract.

\subsection{Credit Using and Rationing of Farmers with Different Risk Attitudes}

- Data shows credit using and rationing of risk averts, risk neutrals and risk lovers respectively. As to risk averts, the credit is mainly used to pay children's tuition, medical care and house building, and the number is 27, 27 and 26 respectively. Then 18 households use credit for holding marriage or funeral ceremonies, while 15 pay for daily necessities. As to credit rationing, 27 households pay for children tuition, 25 for building house and 24 for medical care. As to the degree of credit rationing, the percentages of tuition, marriage or funeral, day necessities, breeding and planting, purchase of farm machinery and private car all reach $100 \%$. So as to risk averts, whether in terms of the absolute quantity or the relative proportion, credit rationing for basic living expenses is comparatively larger than others. Because for farmers in China, tuition, medical care and house building still account for the large proportion of the family total expenses, while the increase of 
inflation and slow rise of farmers' income make it inadequate for farmers to pay their basic expenses. The absolute amount of such credit as investment or life-improvement of running a business, purchase of farm machinery and private car is small, but the percentage of such credit rationing is alarmingly high. Such case shows that farmers with risk aversion attitude also have a strong desire to improve their life. Additionally, farmers under instigation are mainly aged 30 to 50, and the rapid development of China's automobile market and other peers' influence urges them to buy a car. Thus credit rationing appears due to their expected benefit of investment and the incomplete social security.

- As to risk lovers, 39 farmers use credit to run a business of their own, 26 to purchase a car and 23 to build their house. As to the credit rationing, 11 households are for business whereas 7 for cars. In general, credit rationing for risk lovers are relative low, and credit is used for investment and such consumption as improving their life quality.

- Finally, as to risk neutrals, 34 farmers use credit to build house, 28 to run a business and 24 to buy a car. As to the absolute quantity of credit rationing, 15 households buy cars, 14 run a business, 12 build houses and 11 hold marriage or funeral ceremonies. As to credit rationing, breeding and planting amounts to $77.78 \%$; agricultural product processing reaches $75 \%$; purchase of farm machinery is $66.67 \%$; purchase of cars is $62.5 \%$; holding wedding or funeral ceremonies is $61.11 \%$, and all of these have large proportions. As to such risk neutrals, credit rationing is manifested by credit used investment, which serves as an effect evidence of Hypothesis II.

\section{Measurement Model of Risk Attitudes and Farmers' Credit Constraint}

The above part is mainly about the descriptive analysis of sample farmers' risk attitudes, their general features and their credit behavior and results. Then do different attitudes affect farmers' credit behavior and upcoming results? If the answer is yes, then to what degree do such attitudes affect the behaviors and results? Mathematical model, therefore, is needed to analyze and verify it.

\subsection{Choice of Models and Relevant Reasons}

Dependent variables in this paper is binary choice model, Probit and Logit are generally used in discrete choice model and thus both of them are used in the paper to measure the relation between farmers' risk attitudes and the credit restraint.

The basic form of Logit model is as follows:

$$
\log \frac{p_{i}}{1-p_{i}}=\beta_{0}+\sum_{i=1}^{N} \beta_{i} X_{i}+\gamma_{i} Z_{i}+\varepsilon_{i}
$$

$\log \frac{p_{i}}{1-p_{i}}$ stands for the log probability of whether farmers can obtain credit, $X_{i}$ is the vector of farmers' characteristics and geographic features, $Z_{i}$ is farmers' risk attitudes, $\beta_{i}, \gamma_{i}$ is the parameter vector to be estimated, $\varepsilon_{i}$ is the residual item and $\varepsilon_{i}-\left(0, \sigma^{2}\right)$.

$$
\operatorname{probit}(T)=\int_{-\infty}^{T} \varphi(v) \mathrm{d}_{v}
$$

in which, $T=\beta_{0}+\sum_{i=1}^{n} \beta_{i} X_{i}+\gamma_{i} z_{i}$.

The explained variable in the paper is whether farmers obtain credit rationing. The variables mainly include: 1) Geographic features, such as the distances between farmers' house and the city as well as the types of their village. If the farmer lives far away from the city and the village they live is ordinary, the chances to get credit are fewer, the transaction cost is higher and credit constraint is more likely to appear; 2) Farmers' features: the first is the education the householder has received. Generally speaking, the higher education they have gotten, the easier for householders to get access to financial knowledge, the more intention they have to invest and therefore the less the credit constraint becomes. Second, whether one of the family members is a leader in the village. In general, with a leader in the family, the household tend to be richer and have stronger social connection and is less likely to be influenced by credit constraint. The third is the annual average income of the household. 
Households with low income mean lack of pledges and no guarantee to repayment, and they are more affected by credit rationing. The fourth is the number of labor force in the household, which manifests indirectly how much burden the household bears. The more non-labor force, the more burden the household carry, the more credit demand and the more likely they are affected by credit constraint. The fifth is credit using. Other minor variables include population of the household, the age of the householder and the land farmers own; 3) The farmers' risk attitudes have been discussed and analyzed in the last part. Eviews7.2 software is used for data process and measurement (Table 1).

\subsection{Risk Attitudes and Results of Farmers' Credit Rationing}

Based on the survey data, results estimated by Eviews7.2 software are shown in Table 2.

\section{Table 1. Variables and explanations.}

\begin{tabular}{|c|c|}
\hline Variables & Variable explanation \\
\hline \multicolumn{2}{|l|}{ Dependent variables } \\
\hline Credit rationing & $0=$ "no credit rationing", 1 = "having credit rationing" \\
\hline \multicolumn{2}{|l|}{ Independent variables } \\
\hline Distance & (Kilometer) \\
\hline Village types & $1=$ central village, $2=$ non-central village \\
\hline Education & 1 = elementary school and less, 2 = middle school, 3 = high school, $4=$ college and higher \\
\hline Leader & $1=$ yes, $2=$ no \\
\hline $\begin{array}{l}\text { Household annual average } \\
\text { income }\end{array}$ & $\begin{array}{c}1=\text { less than } 10,000 \text { yuan, } 2=10,000-30,000 \text { yuan, } 3=30,000-50,000 \text { yuan, } 4=50,000-70,000 \\
\text { yuan, } 5=70,000-100,000 \text { yuan, } 6=\text { more than } 100,000 \text { yuan }\end{array}$ \\
\hline Labor & (Person) \\
\hline Household scale & (Person) \\
\hline Age & $1=$ below $30,2=30-40,3=40-50,4=50-60,5=$ more than 60 \\
\hline Land & (mu) \\
\hline Credit using & $-1=$ basic living credit, $0=$ improvement credit, $1=$ investment credit \\
\hline Risk attitude & $-1=$ risk lover, $0=$ risk neutral, $1=$ risk averse \\
\hline
\end{tabular}

Table 2. Results of Probit and Logit model influencing credit rationing.

\begin{tabular}{ccc}
\hline \multirow{2}{*}{ Variables } & \multicolumn{2}{c}{ Estimated model result } \\
\cline { 2 - 3 } RA & Probit model (Estimated coefficients) & Logit model (Estimated coefficients) \\
Age & $1.4269^{* * *}$ & $2.4553^{* * *}$ \\
Distance & -0.0576 & -0.0939 \\
Education & $0.0146^{*}$ & $0.0237^{*}$ \\
Income & $-0.2401^{* *}$ & $-0.3948^{* *}$ \\
Labor & $-0.3469^{* * *}$ & $-0.6199^{* *}$ \\
Leader & $-0.0141^{*}$ & $-0.0218^{*}$ \\
Population & -0.1686 & -0.2791 \\
Village & 0.0758 & 0.1243 \\
Land & 0.3359 & 0.5598 \\
Constance & $0.0073^{* *}$ & $0.0081^{* *}$ \\
LR & -1.3384 & -2.3924 \\
R-squared & 92.2600 & 91.6878 \\
Prob (LR statistic) & 0.2845 & 0.2827 \\
AIC & 0.0000 & 0.0000 \\
\hline
\end{tabular}

\footnotetext{
${ }^{* * *}$ Means it is noticeable under $1 \% ;{ }^{* *}$ Noticeable under $5 \%$; ${ }^{*}$ Noticeable under $10 \%$.
} 
As shown in Table 2, the estimated results from Probit and Logit are almost the same, and there are no obvious differences of estimated coefficients as to every variable. Therefore conclusions can be drawn as follows:

First, farmers' risk attitude and credit rationing are in a significant positive correlation. The stronger the farmers' risk aversion is, the more serious credit rationing becomes. And such a conclusion is in correspondence with Hypothesis I. This is mainly because risk averts usually demand more risk premium to compensate risk cost, and thus they are affected by demanded risky credit rationing. In contrast, risk lovers focus more on investment returns and benefit, and they will grasp investment opportunities with the help of credit and consequently they are less likely to be influenced by credit rationing.

Second, distances between farmers' residence and the city, land they have and credit rationing are in a significant positive correlation. If farmers live far away from the city, the transaction cost in financial business tend to be much higher on the one hand; on the other hand, their poor access to information make them more liable to credit rationing. Furthermore, the more land farmers have, the more land investment they have and the more fund they need. In addition, in China rural land remains collectively owned, farmers only have right of management and use, and land transfer market is incomplete, which result in credit rationing.

Third, farmers' education level, income, labor force and credit rationing are in a significant negative correlation. The higher education farmers have means stronger ability to create wealth and less likelihood to suffer from credit rationing. High family income means less need for money and more mortgage ability for credit, and so such family is more likely to obtain credit. Additionally, more labor means more power to become richer and to satisfy family's need for money and less family burden to bear.

Fourth, such variables as age, leader, population and village type don't have significant influence on credit rationing. The older the farmer is, the more accumulated wealth he has, which means less credit rationing. Old age, however, also means less ability to earn money but more expenses, which makes stronger risk aversion and more demanded credit rationing. Effects of age on credit rationing depend on the strength of the two. If there is a leader in the family, the family may have more social capital asset, which in theory means less credit rationing but in practice there is no noticeable result. Such phenomenon arises because in developed area, market mechanism plays a more significant role and financial institutions pay more attention to farmers' wealth in the process of credit. The large the family population is, the more money the family need and the heavier the family burden become, which may lead to credit rationing in theory but in practice this is not the case. This is mainly because the good social security of Chongqing may relieve credit rationing. Farmers of ordinary villages are more liable to credit rationing than those of center villages. Such center villages have better political and economic environment, farmers there have stronger ability to earn money, less credit cost, stronger credit preference and thus less credit rationing. But in practice village type is not a decisive factor to get credit.

\subsection{Credit Using and Rationing under Different Risk Attitudes}

The regression results show that when under different risk attitudes the model with small LR and P is more noticeable than others. Models with smaller AIC is more concise and accurate (Table 3).

In terms of the relation between credit using and rationing, as to risk averts and risk lovers, the influence of credit using on credit rationing is obvious under $10 \%$ and $5 \%$ respectively. With risk averts, the credit using is basic living expenses and their credit rationing is as large as 0.8785 . As to risk lovers, when the credit is used for investment, its credit rationing is 0.2106 . As to risk neutrals, when credit is used to invest, its credit rationing is 0.5941 , but such influence is not noticeable. So as to farmers with different risk attitudes, the effect of credit using on credit rationing is also different, which conforms to Hypothesis II. This is mainly because risk attitudes play a decisive part in farmers' wealth. Generally speaking, farmers with more wealth are more likely to be risk lovers and their credit using is to better their life as well as to gain higher investment rate and benefits while making full of the market opportunities. Farmers with risk aversion attitudes apply for credit to meet their basic living need due to small wealth, and their credit is often short-termed and of small amount.

As to other variables, influence of age on risk preference is negative: the older the farmer, the less the credit rationing. Old age means more accumulated wealth and social asset, which make them less likely be influenced by credit rationing. The influence of education on risk averts and risk lover are both negative and apparent: -1.6290 and -0.7126 respectively. The influences of family income on the above three risk attitudes are all negative and apparent. As to risk averts, whether there is a leader in the family has an obvious influence on credit rationing. The possible reason may be that leaders in the family mean wider social network and stronger ability 
Table 3. Regression result with Logit model under different risk attitudes.

\begin{tabular}{cccc}
\hline & & Estimated model result & \\
\cline { 2 - 4 } Variables & Risk averts & Risk lovers \\
(Estimated coefficients) & $\begin{array}{c}\text { Risk neutrals } \\
\text { (Estimated coefficients) }\end{array}$ & $\begin{array}{c}\text { (Estimated coefficients) } \\
\text { Using }\end{array}$ - $^{*}$ \\
Age & $-0.8785^{*}$ & 0.0699 & $-0.6269^{*}$ \\
Distance & 0.0513 & 0.0059 & 0.0079 \\
Education & $-1.6290^{* *}$ & 0.0059 & $-0.7126^{*}$ \\
Income & $-0.9769^{* *}$ & 0.0272 & $-0.1621^{*}$ \\
Labor & -0.5513 & $-0.0638^{* * *}$ & 0.2841 \\
Leader & $-15.985^{*}$ & 0.0136 & -0.6625 \\
Population & $0.7114^{*}$ & -1.0867 & $0.0540^{*}$ \\
Land & $-0.6353^{*}$ & -0.1539 & $0.1691^{*}$ \\
Constant & 2.9744 & $0.2476^{* *}$ & 2.5155 \\
LR & 18.1687 & 0.5429 & 10.0448 \\
McFadden R-squared & 0.2553 & 18.6717 & 0.0622 \\
Prob (LR statistic) & 0.0199 & 0.0860 & 0.0468 \\
AIC & 0.4010 & 0.0281 & 1.1656 \\
\hline
\end{tabular}

**** Means it is noticeable under 1\%; ${ }^{* *}$ Noticeable under 5\%; ${ }^{*}$ Noticeable under $10 \%$.

to get credit through various channels and thus less credit rationing. As to risk averts and lovers, large family population means more credit rationing. Because more family members means more living expenses and less anti-risk ability and more liable to credit rationing. As to risk averts, the more land the farmers own, the less credit rationing, which is obvious under $10 \%$ and mainly because the land is the main source and guarantee of their income. But to risk lover and neutrals, more land means more credit rationing. Because risk lovers use land management as a major investment for more investment benefit and repay, and thus such farmers need more credit (such as technology input, machines and equipment), which increases credit rationing. To risk averts, the amount of labor force decreases credit rationing, because more labor means more power to get income. But to risk neutrals and lovers, such influence is not noticeable.

\section{Conclusion and Policy}

Little attention has been given to farmers' risk attitudes and credit rationing in China's rural financial market for a long time. The research of this paper shows that farmers' risk attitude and credit rationing are in a significant positive correlation. The stronger the farmers' risk aversion is, the more serious the demanded credit rationing becomes, because risk attitude determines the risk cost and risk premium, and it consequently affects the credit behavior. In addition, the distance of the farmers residence from the city and their land amount have a positive significant influence on credit rationing; while farmers' education degree, income level, family labor force have a negative significant effect on credit rationing. As to farmers with different risk attitudes, their credit using is closely related to credit rationing. As to risk averts, credit rationing of basic living expenses is larger, while to risk lovers, credit rationing of investment and life-improvement expenses is larger.

In order to relieve the farmer's credit rationing and improve its coverage and sustainability, measures must be taken from government, financial institutions and farmers respectively. The government can provide fiscal subsidies to decrease farmers' risk aversion, accelerate and perfect land transfer market to make the farmers' land become their real asset, and speed up urbanization and industrialization to promote farmers' non-agricultural income and scale economy [20]. Financial institutions can make various invisible cost become noticeable, renovate financial products and realign and optimize original products and business process in order to channel, create and fulfill farmers credit needs. As to relieve credit rationing, rural labor training shall be reinforced, the quality of rural human resources shall be promoted and more chances shall be provided for farmers' employment and start of their own business. 


\section{Acknowledgements}

This article is supported by the ministry of education humanities and social science research in western and frontier project "research on entrepreneurship rural household financing problems under the background of urban and rural” (11 XJC790007); is supported by Southwest university central university basic scientific research business expenses special fund project "study on the Chongqing business household financing mechanism and model” (SWU1309229); is supported by Southwest University Shi Zhu base of science and technology innovation fund (SZ201108) and is supported by Rong Chang campus of southwest university enterprise management to cultivate discipline (project code: RCQG207001).

\section{References}

[1] Zhang, L.Y. and Jiang, C. (2011) Theory and Empirical Analysis of Non-price Credit Rationing in China’s Rural Financial Market. Finance Research, 7, 98-113.

[2] Zhu, X. and Li, Z.N. (2007) The Economic Impact of Peasant Household Borrowing-Based on Empirical Research IVQR Model. Systems Engineering Theory and Practice, 2, 68-75.

[3] Li, R. and Zhu, X. (2007) Econometric Analysis of Credit Constraints of Rural Households and Welfare Loss. Economic Research, 2, 146-155.

[4] Zhang, J. (2005) Farmers, Countries and China's Agricultural Credit System: A Long-Term Perspective. Finance Research, 2, 1-12.

[5] Chen, Y. and Luo, D. (2010) Estimates China Farmer's Credit Gap under Credit Constraints. World Economic Papers, 2, 69-80.

[6] Yang, J. (2010) Coverage: The Rural Financial Supply and Demand-Based on 20,000 Farmer Households Borrowing Situation Questionnaire. Review of Financial Development, 3, 121-135.

[7] Inessa, L., Susana, M. and Sánchez (2009) Credit Constraints and Investment Behavior in Mexico’s Rural Economy. The World Bank.

[8] Zhu, X., Shi, Q.H. and Li, R. (2010) The Business Investment Behavior of Peasant Households during the Period of Transition-Based on Yangtze River Delta Tracking 15 Village Farmers. Economics, 9, 713-730.

[9] Zhong, C.P., Xu, C.S. and Sun, H.M. (2010) Credit on Supply, Demand for Credit and Peasant Household Borrowing. Finance Research, 11, 88-100.

[10] Kochar, S.C. and Kirmani, S.N.U.A. (1995) Some Results on Normalized Spacing from Restricted Families of Distributions. Journal of Statistical Planning and Inference, 46, 47-57. http://dx.doi.org/10.1016/0378-3758(94)00095-D

[11] Huo, X.X. and Wang, J. (2010) Investigation and Reflection of the Peasant Household Borrowing Funds in Western-The Case of Luochuan in Shanxi Province. Journal of Northwest Agriculture and Forestry University, 5, 33-37.

[12] Kong, R. and Huo, X.X. (2009) An Empirical Analysis of the Trust, Guilt, and the Choice of Peasant Household Borrowing-Based on the Three Provinces of Gansu, Shanxi, Henan. China's Rural Economy, 11, 50-59.

[13] He, M.S. and Shuai, X. (2008) Research on Financing Constraints and Gaps of Farmer Credit Demand. Finance Research, 7, 66-79.

[14] Ma, X.Y. and Bai, Y.X. (2011) Farmers Individual Character and Credit Constraints: Comparative Analysis of Two Types of Credit Market. Soft Science, 2, 94-98.

[15] Chen, Y. and Luo, D. (2009) Supply Ration and Depression of Demand Interaction under the Influence of Formal Credit Constraints: Study on 1874 Households Farmers Financial Demand Behavior. World Economic, 3, 73-82.

[16] Kim, T.H. (2011) The Measurement of Farmer's Risk Attitudes Using a Non-Structural Approach. Journal of Rural Development, 31, 63-80.

[17] Long, M.F. (1986) Why Peasant Farmers Borrow. American Journal of Agricultural Economics, 50, 991-1008.

[18] Luo, J.Q. (2010) Research on Farmer Credit Demand Class Differences in Zhejiang Province. Rural Economic, 7, 8690.

[19] Zhao, B.Q. (2010) Empirical Research on Farmers Folk Lending Credit Rationing—Based on 600 Rural Households. Social Science Front, 4, 65-71.

[20] Zhu, B.J., Lu, Y.J. and Zhang, L.Y. (2009) Analysis of Peasant Household Borrowing Welfare Effect under the Credit Rationing. China's Rural Economy, 6, 51-61. 
Scientific Research Publishing (SCIRP) is one of the largest Open Access journal publishers. It is currently publishing more than 200 open access, online, peer-reviewed journals covering a wide range of academic disciplines. SCIRP serves the worldwide academic communities and contributes to the progress and application of science with its publication.

Other selected journals from SCIRP are listed as below. Submit your manuscript to us via either submit@scirp.org or Online Submission Portal.
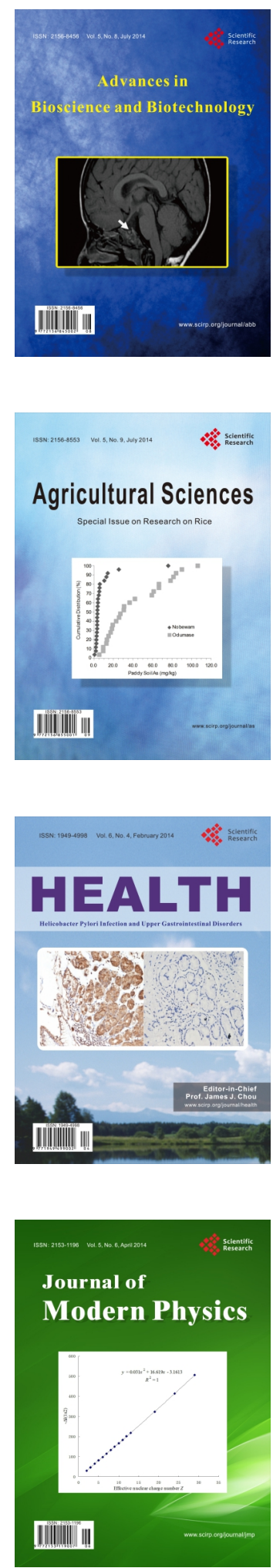
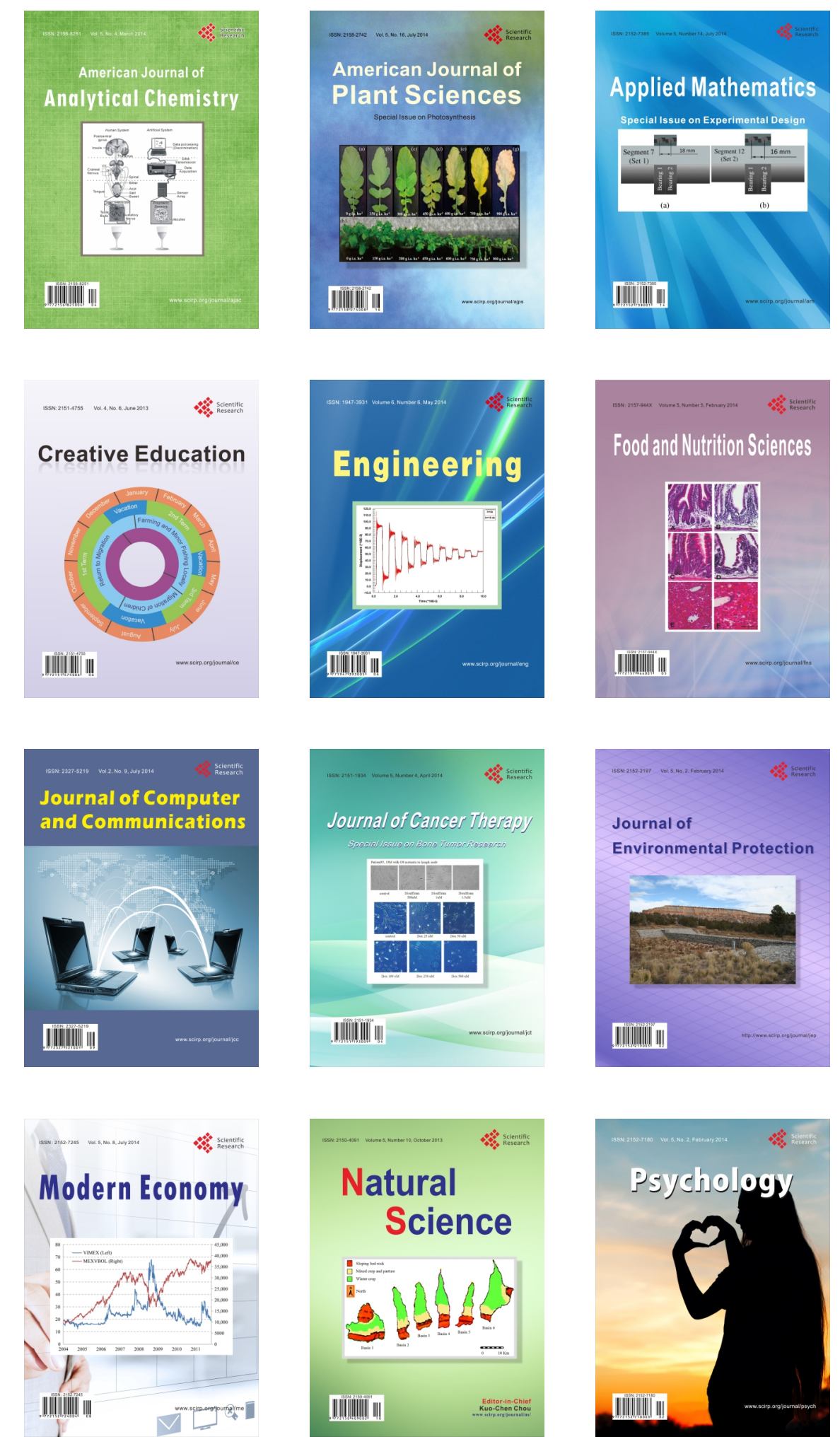